\title{
PENGGUNAAN ALAT PERMAINAN EDUKASI (APE) KEUANGAN BAGI ANAK USIA DINI
}

\author{
Raymond Wahyudi ${ }^{1}$, Nanik Linawati ${ }^{* *}$ \\ 1,2 Program Manajemen Keuangan, Program Studi Manajemen \\ Fakultas Ekonomi, Universitas Kristen Petra \\ Jl. Siwalankerto 121-131, Surabaya \\ Email: 1raymond.wahyudi@petra.ac.id; 2nanikl@petra.ac.id \\ *Penulis korespondensi
}

\begin{abstract}
Abstrak: Perubahan pola konsumsi yang disebabkan oleh kemajuan internet dan teknologi yang begitu pesat dibandingkan tahun-tahun sebelumnya berdampak pada gaya hidup masyarakat yaitu gaya hidup yang mengutamakan kemewahan dan kesenangan semata. Gaya hidup tersebut memberikan dampak negatif terutama pada perilaku konsumsi generasi milenial saat ini. Orang tua dan tenaga pendidik memiliki peran penting untuk memberikan edukasi keuangan sejak dini supaya perilaku konsumtif tersebut dapat dihindarkan. Program Manajemen Keuangan Universitas Kristen Petra mengadakan kegiatan pengabdian masyarakat kepada PAUD dan TK yang telah bekerja sama untuk memberikan edukasi keuangan kepada anak-anak TK melalui penggunaan Alat Permainan Edukasi (APE) Keuangan yang dapat membantu anak-anak belajar mengenai tema menabung dan hidup hemat. Anak-anak TK memberikan respon yang baik terhadap pembelajaran melalui alat permainan tersebut. Para orang tua dan pendidik dapat menggunakan APE Keuangan untuk mengajarkan anakanak mengenai kebiasaan menabung dan hidup hemat dengan mudah dan efisien.
\end{abstract}

Kata kunci: Edukasi keuangan; siswa Taman Kanak-kanak; Alat Permainan Edukasi; perilaku menabung.

\begin{abstract}
Nowadays, the shifting of technology and the internet that has an effect on changing consumption patterns, impacted social lifestyle, is a hedonic and leisure prioritize lifestyle. The lifestyle gives a negative impact to the behaviour of millennial generation especially to their consumption behaviour. Parents and teachers have an important role to teach them early about financial education so they have prevention to the consumptive lifestyle. The Financial Management Programme of Petra Christian University has cooperated with some Early Childhood School and Kindergarten to teach the children about financial education using Education games. Financial education could easily be learned through education games so the children could understand about saving behaviour and spending wisely. The children responded positively to the lesson through education games. The parents and teacher could teach the children easily and efficiently about saving attitude and spending wisely using the education games.
\end{abstract}

Keywords: Financial education; kindergarten students; Education games; saving behaviour.

\section{PENDAHULUAN}

Pada era globalisasi saat ini, perilaku masyarakat Indonesia mengalami perubahan yang menyeluruh terutama dalam melakukan kegiatan konsumsi. Umumnya, perilaku konsumsi yang berubah pada masyarakat tersebut menyebabkan perubahan gaya hidup yang menyeluruh karena disebabkan oleh adanya perkembangan teknologi dan internet yang sangat cepat (Marina, 2020). Gaya hidup yang mengutamakan kemewahan dan kesenangan semata menjadi ciri utama dalam pola konsumsi masyarakat Indonesia saat ini meng- akibatkan dampak negatif bagi perilaku generasi sekarang yaitu generasi milenial. Perilaku konsumtif pada generasi milenial antara lain memilih untuk menggunakan dana yang dimiliki untuk membeli barang yang sesuai dengan tren yang ada tanpa mempertimbangkan masa depan dengan menyisihkan tabungan dan investasi (Laturette et al., 2021). Fakta tersebut perlu diperhatikan oleh para orang tua dan tenaga pendidik yang memiliki peran penting dalam memberikan edukasi keuangan supaya anak dapat menghindari perilaku konsumtif tersebut (Sumiyati, 2017). Edukasi keuangan yang diberikan semenjak dini akan me- 
nolong anak untuk memiliki kemandirian keuangan di masa mendatang karena semakin dini anak mendapatkan edukasi keuangan maka dampak dari edukasi yang diberikan tersebut akan mengarahkan perilaku anak tersebut di masa mendatang (Wahyudi \& Linawati, 2017). Edukasi keuangan yang diberikan kepada anak dapat dimulai dengan pengenalan yang mendasar mengenai pola gaya hidup yang sederhana. Pola gaya hidup yang sederhana ini penting untuk dikenal oleh anak-anak supaya perilaku yang terbentuk oleh anak-anak didasarkan oleh kesadaran akan pentingnya pemenuhan kebutuhan utama seperti makanan bergizi, tempat tinggal, pendidikan dan kesehatan daripada keinginan yang tidak mendesak (Kemendikbud, 2016). Edukasi keuangan tersebut juga sejalan dengan studi yang dilakukan oleh Setianingsih (2019) bahwa gaya hidup sederhana perlu diajarkan kepada anak semenjak dini sebagai salah satu nilai yang perlu ditanamkan untuk mengantisipasi dampak negatif dari gaya hidup hedonisme.

Anak-anak pada usia dini membutuhkan stimulasi untuk membantu perkembangan diri anak. Stimulasi anak sejak dini memang perlu dilakukan hingga usia 3 tahun karena pada tahap usia tersebut otak anak sedang mengalami perkembangan pesat dan stimulasi yang terus menerus diterima oleh anak akan membantu meningkatkan kecerdasan anak di masa mendatang (Wisnubrata, 2020). Para orang tua dapat memberikan stimulasi tersebut salah satunya dengan menggunakan Alat Permainan Edukasi (APE) yang akan mendorong anak tersebut untuk mengembangkan kemampuan berpikir dan kreativitas. Namun para orang tua perlu memperhatikan pemilihan APE yang sesuai dengan usia dan tahap perkembangan anak supaya anak memperoleh manfaat yang maksimal dari APE yang diberikan (Ramadhini, 2021). Para orang tua seringkali kebingungan dalam memilih APE yang tepat dan hanya berdasarkan pada bentuk mainan atau trend yang ada di media sosial padahal APE tersebut seharusnya bermanfaat bagi anak sebagai media pembelajaran. Misalnya pemilihan mainan yang sesuai bagi anak usia 1-3 tahun yaitu mainan yang dapat mendukung perkembangan kemampuan identifikasi anak terhadap lingkungannya supaya membantu stimulasi kemampuan berpikir, motorik halus dan memperkuat otot-otot anak seperti puzzle, permainan bola dan menggambar (Noya, 2021).

Melalui APE yang telah dikembangkan melalui program pengabdian masyarakat Universitas Kristen Petra, kami memiliki harapan bahwa para orang tua dan tenaga pendidik dapat berpartisipasi dalam memberikan edukasi keuangan kepada anak-anak mulai dari usia dini. Pengembangan
APE yang dilakukan telah berlangsung semenjak tahun 2014 hingga saat ini dimana puluhan sekolah TK dan PAUD di Surabaya telah menjadi mitra dalam pengembangan APE tersebut. APE juga memerlukan kesadaran dari orang tua dan tenaga pendidik akan pentingnya edukasi keuangan bagi anak usia dini sehingga kajian dalam materi ajar bagi para orang tua dan tenaga pendidik akan sangat diperlukan. Peran aktif dari orang tua dan tenaga pendidik akan mempermudah anak-anak untuk menerima manfaat dalam edukasi keuangan yang diberikan melalui APE.

\section{METODE PELAKSANAAN}

Metode yang digunakan dalam kegiatan pengabdian masyarakat yang dilaksanakan oleh program manajemen keuangan Universitas Kristen Petra melalui beberapa tahapan yang diperlukan antara lain tahapan persiapan, tahapan pelaksanaan dan tahapan evaluasi. Pada tahapan persiapan, terdapat pembentukan kelompok pengajar yang terdiri dari 4-5 mahasiswa dengan pendampingan dari 1 dosen dan kemudian melakukan perkenalan pada mitra PAUD dan TK yang akan bekerja sama untuk melaksanakan kegiatan pengabdian masyarakat. Perkenalan pada mitra PAUD dan TK tersebut berguna untuk mengenal kebutuhan mitra PAUD dan TK dalam edukasi keuangan yang akan diberikan beserta dengan persiapan APE Keuangan yang akan digunakan nantinya saat pelaksanaan kegiatan. Setiap kelompok pengajar dapat menyesuaikan kurikulum yang akan dipakai di dalam pelaksanaan kegiatan berdasarkan kebutuhan masing-masing mitra PAUD dan TK.

Setelah melalui tahapan persiapan yang telah disetujui oleh mitra PAUD dan TK untuk dilaksanakan, tahapan berikutnya adalah tahapan pelaksanaan. Setiap kelompok pengajar melaksanakan kegiatan pengabdian masyarakat tersebut di masing-masing mitra PAUD dan TK yang telah dikunjungi sebelumnya. Setiap kelompok pengajar tersebut menjalankan 5 kali pertemuan dengan durasi sekitar 90 menit selama bulan Maret 2020. Para mahasiswa menggunakan APE Keuangan sebagai sarana untuk memberikan edukasi keuangan sesuai dengan kurikulum yang direncanakan bagi para siswa PAUD dan TK. Selama kegiatan berlangsung, setiap kelompok pengajar melakukan observasi dan monitoring terhadap proses pengajaran yang diberikan kepada anak PAUD dan TK melalui penggunakan alat permainan tersebut. Observasi adalah sebuah teknik pengumpulan data melalui pengamatan secara sistematis terhadap perilaku objek penelitian dan hasil observasi dapat didokumentasikan sebagai sumber data yang akurat (Ni'matuzahroh; \& 
Prasetyaningrum, 2018). Dosen pendamping melakukan pengawasan cukup ketat dalam satu pertemuan yang dilakukan masing-masing kelompok pengajar berdasarkan jadwal yang telah ditentukan supaya mengetahui secara langsung kendala yang terjadi saat kegiatan dilaksanakan dan bersama-sama mitra mengupayakan solusi untuk menyelesaikannya.

Lalu dalam tahapan evaluasi, setiap kelompok pengajar akan memberikan laporan dan dokumentasi atas kegiatan yang dilakukan beserta hasil wawancara dengan para guru masing-masing mitra PAUD dan TK yang telah terlibat dalam pelaksanaan kegiatan pengabdian masyarakat tersebut. Bentuk dokumentasi kegiatan dapat berupa foto atau video untuk memberikan gambaran situasi pelaksanaan kegiatan dengan jelas sebagai kelengkapan laporan. Hal ini penting supaya pelaksana pengabdian kepada masyarakat mampu mengetahui proses dari awal hingga akhir sebagai wadah pembelajaran bersama melalui proses refleksi diri masing-masing.

\section{HASIL DAN PEMBAHASAN}

\section{Alat Permainan Edukasi (APE) Keuangan}

Alat Permainan Edukasi (APE) Keuangan yang digunakan dalam kegiatan pengabdian masyarakat berikut memang dirancang khusus untuk memenuhi ciri-ciri alat permainan edukasi yang tepat bagi anak usia dini, dengan tujuan antara lain mudah digunakan bagi anak usia PAUD atau TK, memiliki fungsi dalam mengembangkan aspek-aspek dalam diri anak, memberikan stimulasi bagi anak melalui bentuk dan cara memainkannya, memenuhi syarat keamanan untuk anak, memotivasi anak untuk mengembangkan kreativitas dan terdapat manfaat edukatif (Guslinda \& Kurnia R., 2018)

Boneka, kartu bergambar dan puzzle sebagai alat permainan edukasi Keuangan menggunakan tema menabung dan tema hidup hemat untuk mengenalkan anak-anak TK mengenai cara pengelolaan keuangan secara sederhana semenjak dini. Tema menabung yang diberikan kepada anak-anak TK tersebut merupakan aspek yang perlu dipelajari oleh anak-anak sejak dini supaya anak-anak memahami fungsi uang sebagai alat pembayaran dan memiliki kebiasaan untuk menyisihkan uang yang dimiliki sebagai tabungan di masa depan sesuai dengan cita-cita anak-anak tersebut. Selain itu, tema hidup hemat juga merupakan edukasi keuangan yang perlu diketahui oleh anak-anak sejak dini supaya anak-anak mampu membedakan kebutuhan dan keinginan yang nantinya akan memberikan dampak pada kebiasaan untuk berbelanja yang sesuai dengan kebutuhan (Kemendikbud, 2016).

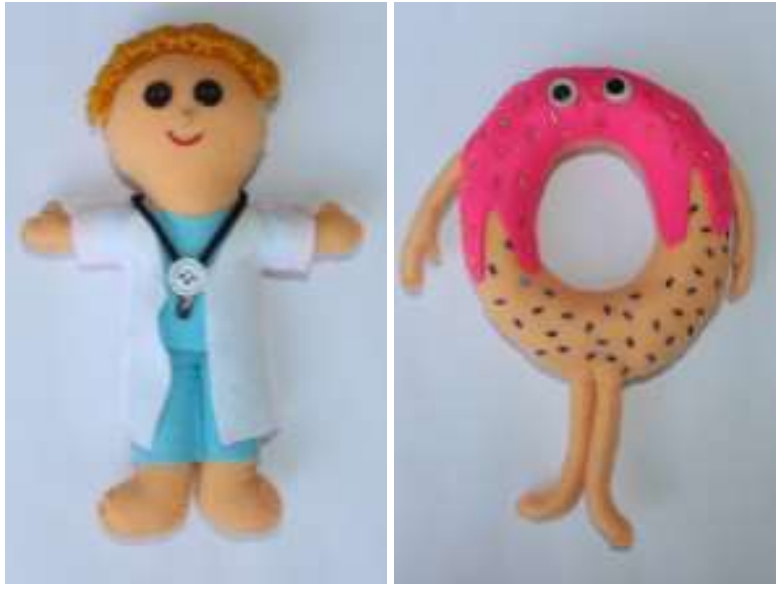

Gambar 1. Contoh Boneka sebagai APE Keuangan

\section{Tujuan APE Keuangan}

Tujuan APE yang digunakan dapat dibagi dalam dua kelompok antara lain (Fadlillah, 2017):

1. Tujuan Alat Permainan Edukasi bagi anak sebagai berikut:

- Untuk mempermudah cara belajar anak,

- Untuk mengembangkan kemampuan berpikir anak dan

- Untuk meningkatkan konsentrasi anak.

2. Tujuan Alat Permainan Edukasi bagi pendidik sebagai berikut

- Untuk sarana pembelajaran yang efektif,

- Untuk mengembangkan metode pengajaran yang dimiliki, dan

- Untuk membantu pengajaran yang efisien.

\section{Pelaksanaan Kegiatan}

Pelaksanaan kegiatan pengabdian masyarakat yang akan diadakan pada mitra TK di Surabaya melibatkan mahasiswa program manajemen keuangan UK. Petra berjumlah 50 orang mahasiswa dan 4 orang dosen pendamping. Para mahasiswa tersebut terbagi dalam 11 kelompok pengajar dimana terdiri dari 4-5 orang mahasiswa yang didampingi oleh 1 orang dosen pendamping. Setiap kelompok mengirimkan proposal kegiatan kepada mitra TK yang akan bekerja sama untuk menentukan jadwal pelaksanaan kegiatan pengabdian masyarakat. Para mitra TK yang telah menyetujui jadwal pelaksanaan kegiatan pengabdian masyarakat tersebut maka setiap kelompok pengajar menyiapkan sarana Alat Permainan Edukasi yang dibutuhkan dan kurikulum yang akan diberikan berdasarkan kebutuhan masingmasing mitra TK yang telah dikunjungi sebelumnya. Namun sebagian besar kelompok pengajar mengalami kendala dalam melaksanakan pertemuan karena adanya pandemi Covid-19 yang mewajibkan TK untuk menutup semua kegiatan belajar mengajar pada pertengahan bulan Maret 
2020 sehingga pelaksanaan kegiatan tidak dapat dilakukan dalam kondisi tersebut. Berikut adalah daftar sekolah TK di Surabaya yang telah bekerja sama dalam kegiatan pengabdian masyarakat UK. Petra seperti pada Tabel 1.

Setelah melaksanakan seluruh pertemuan pada mitra TK yang dilakukan oleh masing-masing kelompok pengajar pada kondisi sebelum pandemi Covid-19 maka kemudian dapat memasuki tahapan berikutnya yaitu tahapan evaluasi. Melalui tahapan evaluasi, setiap kelompok pengajar telah mengumpulkan hasil dari observasi yang dilakukan bentuk laporan tertulis beserta dengan dokumentasi selama pertemuan berlangsung. Dokumentasi yang dilakukan berupa foto atau video untuk memberi penjelasan terhadap situasi di dalam pertemuan tersebut. Setiap kelompok pengajar juga melaksanakan wawancara terhadap guru mitra TK untuk memperoleh evaluasi dari pengamatan yang dilakukan para guru mitra TK selama pelaksanaan kegiatan dari awal hingga akhir khususnya dalam hal penggunaan APE Keuangan bagi para siswa TK.

Berikut beberapa kurikulum yang diberikan kepada mitra TK menggunakan APE Keuangan dalam kegiatan pengabdian masyarakat pada Tabel 2.

\section{Kegiatan Pengabdian Masyarakat di TK Kartini Genteng}

Pihak TK Kartini Genteng telah menyetujui jadwal pelaksanaan tersebut dan menyediakan ruang di salah satu kelas sebagai ruang pertemuan kegiatan pengabdian masyarakat. Pada pertemuan tanggal 11 Maret 2020, salah satu dosen ikut mendampingi kelompok pengajar untuk mengamati proses pelaksanaan pertemuan tersebut.

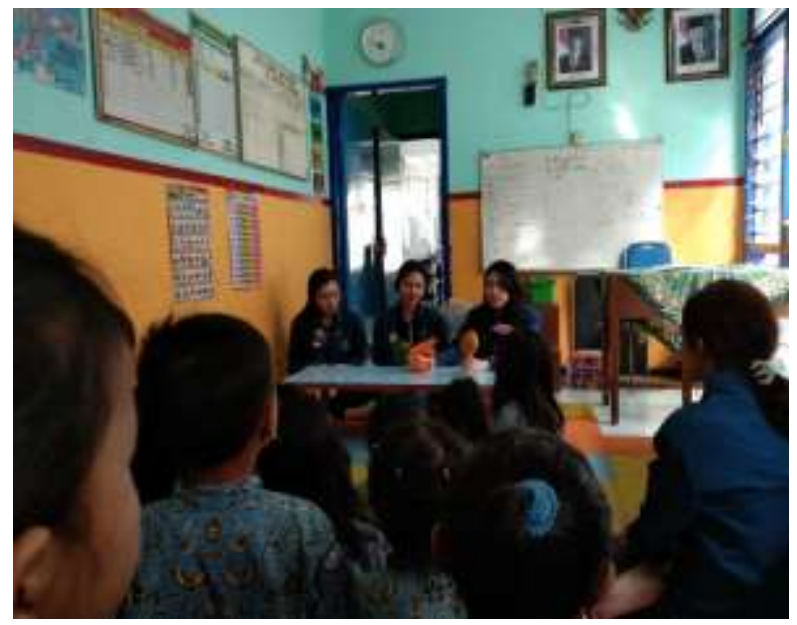

Gambar 2. Kegiatan Edukasi menggunakan Panggung

Tabel 1. Daftar Sekolah-sekolah TK pada Kegiatan Pengabdian Masyarakat UK. Petra Tahun 2020

\begin{tabular}{clccc}
\hline No & \multicolumn{1}{c}{ Nama TK } & Jumlah Murid & Jumlah Guru & Jadwal Pertemuan \\
\hline 1. & TK. Yasporbi & 15 & 2 & Tgl. 4, 9, 11 Maret \\
2. & TK. Karya Widya & 20 & 3 & Tgl. 2, 3, 10 Maret \\
3. & TK. Anak Ceria & 12 & 3 & Tgl. 4, 6, 11, 13 Maret \\
4. & TK. St. Caecilia I & 34 & 3 & Tgl. 4, 9, 11 Maret \\
5. & TK. Rainbow Kiddy & 12 & 1 & Tgl. 4, 9, 11 Maret \\
6. & TK. Bethel Sulung 3 & 10 & 2 & Tgl. 3, 9, 10 Maret \\
7. & TK. Pelita Permai & 53 & 5 & Tgl. 9, 11, 13 Maret \\
8. & TK. Bina Nurani & 29 & 4 & Tgl 6, 9, 13 Maret \\
9. & TK. Kartini Genteng & 25 & 2 & Tgl 4, 6, 11, 13 Maret \\
10. & TK. Kartini Kutisari & 24 & 2 & Tgl 26 Feb, 2, 4, 9, 11 Maret \\
11. & TK. Bisma & 37 & 2 & Tgl 9, 11, 13 Maret \\
\hline
\end{tabular}

Tabel 2. Contoh Kurikulum Kegiatan Pengabdian Masyarakat bagi Mitra TK

\begin{tabular}{|c|c|c|}
\hline No & Kegiatan & Tujuan \\
\hline 1. & $\begin{array}{l}\text { Edukasi dengan boneka "Hidup } \\
\text { Sehat Hemat" }\end{array}$ & $\begin{array}{l}\text { Mendorong setiap siswa untuk memilih makanan yang sehat bagi tubuh serta } \\
\text { menyadari bahwa uang yang dimiliki saat ini perlu dihemat }\end{array}$ \\
\hline & $\begin{array}{l}\text { Kartu Kembar Hidup Sehat } \\
\text { Hemat }\end{array}$ & Mengajar ketelitian pada siswa melalui gambar mengenai hidup sehat hemat \\
\hline 3. & $\begin{array}{l}\text { Kartu Domino Hidup Sehat } \\
\text { Hemat }\end{array}$ & Mengajar siswa untuk mencocokkan gambar mengenai hidup sehat hemat \\
\hline 4. & $\begin{array}{l}\text { Mewarnai Gambar Hidup Sehat } \\
\text { Hemat }\end{array}$ & Mengasah jiwa seni siswa melalui pilihan gambar mengenai hidup sehat hemat \\
\hline 5. & $\begin{array}{l}\text { Puzzle huruf dan puzzle gambar } \\
\text { hidup hemat }\end{array}$ & $\begin{array}{l}\text { nenyusun kata atau gambar sambil memahami arti } \\
\text { lat }\end{array}$ \\
\hline 6. & $\begin{array}{l}\text { Edukasi dengan Boneka } \\
\text { "Hidupku Perlu Biaya" }\end{array}$ & $\begin{array}{l}\text { Memberikan kesadaran bagi siswa untuk mempersiapkan dana untuk kebutuhan } \\
\text { di masa depan serta membangkitkan minat menabung pada siswa Boneka di TK } \\
\text { Kartini Genteng }\end{array}$ \\
\hline
\end{tabular}


Menurut hasil observasi yang dilakukan oleh kelompok pengajar di TK Kartini Genteng, anakanak TK yang diajar tersebut memiliki antusiasme dan semangat yang tinggi untuk mengikuti setiap kegiatan juga termasuk di dalamnya terdapat kegiatan yang menggunakan Alat Permainan Edukasi Keuangan. Anak-anak TK Kartini Genteng diajak untuk mengenal cara hidup yang sehat dan hemat melalui edukasi yang diberikan. Melalui edukasi menggunakan kegiatan peragaan panggung boneka, kelompok pengajar mengajak anakanak TK untuk mengenal peran pada boneka yang mewakili makanan yang sehat. Lalu para mahasiswa menggunakan cerita yang menarik untuk menjelaskan manfaat dari makanan yang sehat tersebut dan memberikan pertanyaan untuk mendorong anak-anak TK lebih memahami edukasi yang diberikan tersebut. Kelompok pengajar juga memberikan edukasi mengenai pentingnya mempersiapkan dana untuk kebutuhan di masa depan menggunakan boneka. Boneka tersebut menggambarkan peran anak-anak yang bersekolah, pasangan yang menikah, pasangan yang memiliki anak hingga pasangan yang lanjut usia. Pada kegiatan peragaan panggung boneka tersebut, anakanak TK kurang memahami cerita yang dibawakan oleh para mahasiswa dan tidak dapat memberikan respon pada saat mahasiswa melakukan interaksi maupun pertanyaan yang diberikan. Hal tersebut dimungkinkan karena faktor usia mereka yang memang masih dominan based on kesenangan, belum pada level benar atau salah, Melalui kegiatan mencocokkan gambar di dalam kegiatan kartu kembar, para mahasiswa membagi anakanak TK dalam beberapa kelompok yang setiap kelompoknya berisi 2 anak dan setiap kelompok bergantian untuk mencocokkan gambar pada kartu kembar sehingga permainan dapat berlangsung dengan tertib. Anak-anak TK menunjukkan respon yang aktif terhadap kegiatan tersebut dan mengikuti instruksi dengan baik. Selama kegiatankegiatan tersebut berlangsung, para guru TK membantu dalam mengawasi anak-anak TK supaya tetap menerima edukasi yang diberikan dengan baik.

Para guru TK Kartini Genteng juga ikut serta dalam pertemuan yang dilaksanakan untuk membantu para mahasiswa dalam melakukan pendekatan terhadap anak-anak TK terutama anak-anak yang cenderung kurang aktif. Penilaian para guru TK Kartini Genteng terhadap edukasi menggunakan APE Keuangan seperti panggung boneka, kartu domino, kartu kembar dan puzzle bergambar berdasarkan hasil wawancara yang diperoleh menyatakan bahwa edukasi tersebut dapat dipahami dengan mudah oleh anak-anak TK karena menggunakan alat permainan edukasi dengan bentuk yang menarik juga memperoleh pengalaman yang menyenangkan saat memainkannya.

\section{Kegiatan Pengabdian Masyarakat di TK Bethel Sulung 3}

Jadwal pelaksanaan kegiatan pengabdian masyarakat di TK Bethel Sulung 3 yang telah ditentukan adalah pada tanggal 3, 9 dan 10 Maret 2020. Kegiatan tersebut menggunakan waktu belajar mengajar anak-anak TK dengan durasi sekitar 90 menit. Lalu dosen pendamping juga dapat ikut mengawasi proses pelaksanaan kegiatan tersebut pada pertemuan tanggal 10 Maret 2020.

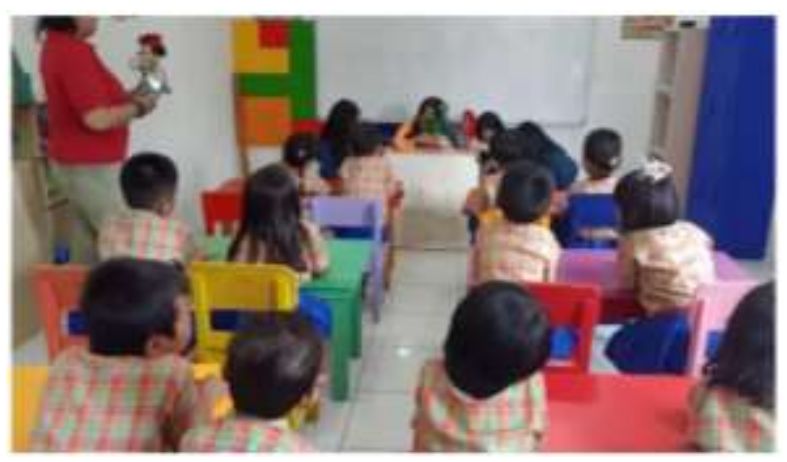

Gambar 3. Kegiatan Edukasi menggunakan Panggung Boneka di TK Bethel Sulung 3

Berdasarkan observasi dari kelompok pengajar di TK Bethel Sulung 3, pelaksanaan kegiatan pada TK Bethel Sulung 3 juga memperoleh respon yang baik dari anak-anak TK pada setiap pertemuan yang berlangsung. Pada kegiatan edukasi menggunakan peragaan panggung boneka, anakanak diajarkan untuk memilih makanan yang sehat dan dapat menerapkan cara hidup yang hemat dengan peran yang dimainkan oleh masingmasing mahasiswa menggunakan boneka tersebut. Para mahasiswa memperkenalkan peran dari setiap boneka tersebut kepada anak-anak yang berbentuk berbagai macam makanan sehat. Kemudian para mahasiswa memberikan cerita yang menunjukkan manfaat dari makanan sehat tersebut dan dapat mengurangi pengeluaran untuk makanan yang tidak sehat. Anak-anak TK tersebut bersedia mendengarkan dengan seksama materi yang disampaikan melalui kegiatan panggung boneka tersebut dan dapat memberikan respon yang baik selama aktivitas berlangsung. Pada kegiatan kartu kembar, para mahasiswa membagi anak-anak TK dalam 2 kelompok kecil dan setiap kelompok kecil didampingi oleh 2 mahasiswa untuk memudahkan penyampaian edukasi dan penjelasan cara bermain kepada anak-anak TK. Anak-anak TK dapat menyusun kartu kembar hidup hemat sesuai instruksi yang diberikan dan aktif dalam menjawab pertanyaan yang diberikan oleh mahasiswa. Anak-anak TK juga mudah memahami kegiatan kartu domino meskipun permainan tersebut belum pernah dimainkan karena kartu domino tersebut menggunakan gambar yang menarik dan mudah untuk dihafalkan. 
Melalui hasil wawancara dari para guru TK Bethel Sulung 3 yang turut mendukung dalam beberapa pelaksanaan kegiatan juga dapat diketahui bahwa penilaian terhadap edukasi menggunakan boneka dan kartu bergambar sebagai APE Keuangan sangat membantu untuk memudahkan anak-anak TK dalam memahami materi yang disampaikan oleh mahasiswa karena cara penyampaian yang dilakukan oleh mahasiswa cukup menarik dan memberikan pengalaman bagi anakanak TK sebuah pembelajaran yang menyenangkan.

\section{Kegiatan Pengabdian Masyarakat di TK Bisma}

Berdasarkan persetujuan pihak sekolah TK Bisma, jadwal pelaksanaan kegiatan pengabdian masyarakat di TK Bisma dilakukan pada tanggal 4, 9, 11, dan 13 Maret 2020. Salah satu dosen pendamping dapat terlibat dalam mengamati proses pelaksanaan kegiatan tersebut pada pertemuan tanggal 11 Maret 2020.

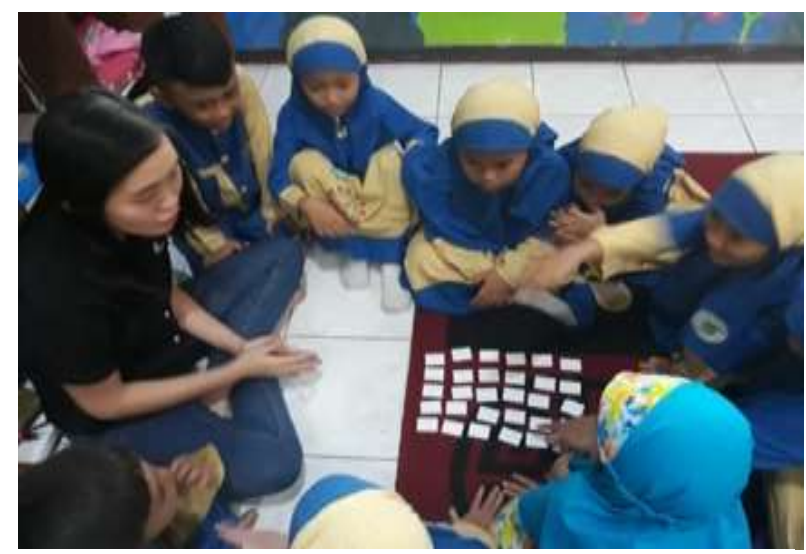

Gambar 4. Kegiatan menyusun kartu bergambar di TK Bisma

Berdasarkan observasi yang diperoleh dari kelompok pengajar di TK Bisma selama pertemuan menunjukkan bahwa respon anak-anak TK cepat dan aktif dalam memberikan tanggapan setiap instruksi yang diberikan oleh para mahasiswa meskipun kegiatan-kegiatan yang diberikan tersebut belum pernah dilakukan oleh anak-anak TK. Dalam pelaksanaan kegiatan menyusun kartu bergambar bertema hidup sehat hemat, para mahasiswa membagi anak-anak TK dalam 4 kelompok kecil dan setiap kelompok kecil didampingi oleh 1 mahasiswa supaya para mahasiswa dapat memberikan edukasi dan mengajarkan cara bermainnya dengan mudah dalam setiap kelompok kecil. Pada kegiatan menyusun puzzle huruf dan puzzle bergambar juga menggunakan metode yang sama dalam menyampaikan penjelasan mengenai edukasi dan cara bermain dalam kegiatan tersebut yaitu membagi anak-anak TK dalam kelompok kecil sehingga edukasi dapat mudah diberikan kepada anak-anak TK. Anak-anak TK dapat memahami dengan cepat setiap kegiatan tersebut dan dapat menjawab pertanyaan yang diberikan oleh para mahasiswa. Kegiatan mewarnai dan kegiatan panggung boneka juga dilaksanakan dengan lancar meskipun terdapat anak-anak TK yang masih cenderung diam dan masih belum terlibat aktif dalam kegiatan-kegiatan tersebut.

Menurut hasil wawancara guru-guru TK yang juga ikut terlibat dalam pelaksanaan kegiatan tersebut, kegiatan yang menggunakan boneka dan kartu bergambar sebagai APE Keuangan dengan tema hidup sehat hemat sangat mudah untuk diajarkan bagi anak-anak TK karena bentuknya yang menarik dan memberikan pengalaman yang menyenangkan bagi anak-anak TK sehingga anakanak TK memperoleh edukasi dengan mudah dan termotivasi untuk menerapkan edukasi tersebut.

\section{Kegiatan Pengabdian Masyarakat di TK St. Caecilia I}

Pihak sekolah TK St. Caecilia I dan kelompok pengajar telah menentukan jadwal pelaksanaan kegiatan pengabdian masyarakat untuk diadakan pada tanggal 4, 9, dan 11 Maret 2020. Proses pelaksanaan kegiatan tersebut juga ikut diawasi oleh salah satu dosen pendamping bagi kelompok pengajar pada pertemuan tanggal 9 Maret 2020.

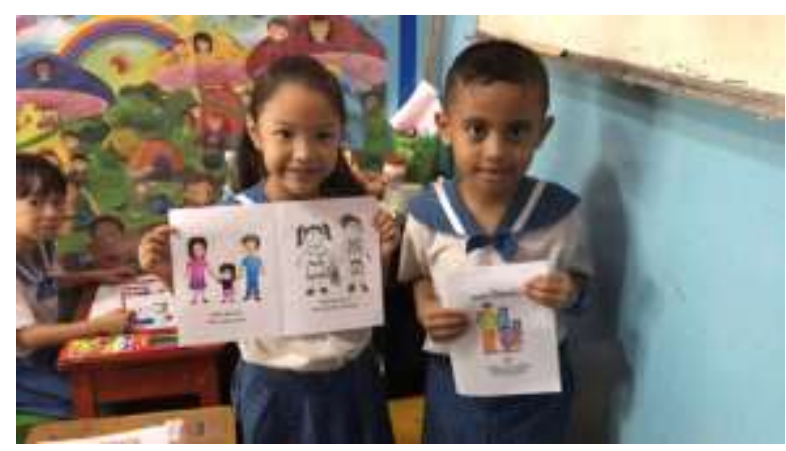

Gambar 5. Kegiatan mewarnai di TK St. Caecilia I

Hasil pengamatan yang dilakukan oleh kelompok pengajar di TK St. Caecilia I memberikan gambaran bahwa anak-anak TK sangat bersemangat dalam mengikuti setiap kegiatan yang berlangsung sehingga pelaksanaan kegiatan dapat berjalan dengan lancar. Pelaksanaan kegiatan kartu domino dan kartu kembar dilakukan secara berkelompok dimana anak-anak TK dimasukkan dalam kelompok berisi 7-8 anak supaya pelaksanaan dapat berjalan dengan tertib. Para mahasiswa memberikan penjelasan tentang cara hidup sehat dan hemat melalui kegiatan tersebut. Anakanak TK dapat segera memahami instruksi yang diberikan oleh mahasiswa dalam kegiatan menyu- 
sun kartu domino maupun kartu kembar dan menerima edukasi mengenai hidup sehat hemat dengan baik. Kegiatan peragaaan panggung boneka mengajarkan mengenai persiapan dana untuk masa depan bagi anak-anak TK. Kegiatan tersebut juga mendapatkan respon yang aktif dari anak-anak TK melalui interaksi yang terjadi antara mahasiswa yang berperan dengan anak-anak TK selama kegiatan berlangsung. Guru TK juga turut mendukung kegiatan yang berlangsung dalam mengawasi anak-anak TK supaya tetap mendengarkan dan berkonsentrasi pada edukasi yang diberikan oleh mahasiswa.

Penggunaan boneka dan kartu bergambar sebagai APE Keuangan menurut hasil wawancara para guru TK yang telah berpartisipasi dalam kegiatan tersebut merupakan cara yang efektif bagi anak-anak TK untuk memahami edukasi keuangan dengan mudah karena memiliki bentuk yang menarik dan memberikan motivasi bagi anak-anak TK dalam menerapkan edukasi tersebut.

Berdasarkan keseluruhan respon anak-anak pada mitra TK yang mengikuti kegiatan pengabdian masyarakat, menunjukkan bahwa boneka, kartu bergambar dan puzzle sebagai APE Keuangan yang digunakan, telah sesuai dengan tujuan dalam penggunaan APE. Antusiasme anakanak TK yang melakukan terlibat dalam kegiatan tersebut juga menunjukkan bahwa pembelajaran menggunakan APE Keuangan tersebut dapat berhasil diterima oleh anak-anak dengan baik. Berdasarkan gambaran respon yang ditunjukkan oleh anak-anak TK selama pembelajaran tersebut juga dapat diketahui APE sangat efektif untuk menjadi sarana pembelajaran karena anak-anak secara umumnya gemar akan permainan yang menyenangkan dan pendidik dapat menggunakan alat permainan untuk memberikan pengajaran kepada anak-anak (Zaman, 2011).

\section{SIMPULAN}

Edukasi keuangan perlu diajarkan kepada anak-anak sejak dini supaya anak-anak memiliki kebiasaan dalam pengelolaan keuangan secara mandiri. Anak-anak dapat terhindar dari kebiasaan hidup yang boros dan konsumtif melalui edukasi keuangan yang diberikan oleh para pendidik dan orang tua. APE Keuangan dapat digunakan sebagai media pembelajaran bagi anak-anak TK supaya dapat memahami tema menabung dan hidup hemat dengan mudah. Anak-anak TK sangat antusias dalam menerima pembelajaran melalui penggunaan boneka, kartu bergambar dan puzzle sebagai APE Keuangan tersebut sehingga hal tersebut memudahkan para pendidik untuk memberikan edukasi keuangan yang menarik dan menyenangkan bagi anak-anak sejak dini. Para pendidik dan orang tua dapat memanfaatkan APE Keuangan tersebut untuk mengajarkan edukasi keuangan bagi anak-anak sejak dini secara mudah dan efisien. APE Keuangan tersebut diharapkan mampu memberikan dampak bagi perkembangan edukasi keuangan yang dapat diajarkan sejak dini dan mendukung program pemerintah dalam menerapkan edukasi keuangan dalam keluarga.

\section{REKOMENDASI}

Penggunaan APE Keuangan kepada Anak Usia Dini dapat menjadi bahan referensi bagi para orang tua dan tenaga pendidik untuk mengembangkan metode pembelajaran yang berkaitan dengan edukasi keuangan. APE Keuangan juga dapat menjadi pertimbangan untuk dimanfaatkan melalui media digital yang memudahkan anakanak untuk mengakses pembelajaran melalui berbagai platform.

\section{UCAPAN TERIMA KASIH}

Kegiatan pengabdian masyarakat yang telah dilakukan pada Maret 2020 merupakan dukungan dari Program Manajemen Keuangan Universitas Kristen Petra dan para mahasiswa yang telah berpartisipasi dalam mata kuliah keuangan personal pada semester Gasal 2019/2020. Kegiatan ini juga merupakan hasil kerjasama dengan beberapa TK yang berada di Surabaya. Kami selaku peneliti dan dosen pengampu mata kuliah keuangan personal mengucapkan terima kasih sebesar-besarnya kepada para pihak yang telah disebutkan dan para pihak terkait yang belum tercantumkan karena telah memberikan kesempatan untuk melaksanakan kegiatan pengabdian masyarakat tersebut.

\section{DAFTAR PUSTAKA}

Fadlillah, M. (2017). Bermain \& Permainan Anak Usia Dini (1st ed.). Prenadamedia group.

Guslinda, \& Kurnia, R. (2018). Media Pembelajaran Anak Usia Dini. Surabaya, Jawa timur: CV. Jakad Publishing.

Kementerian Pendidikan dan Kebudayaan. (2016, December). Buku Seri Pendidikan Orang Tua: Menanamkan hidup sederhana [Pdf]. Jakarta: Kementerian Pendidikan dan Kebudayaan.

Laturette, K., Widianingsih, L., \& Subandi, L. (2021). Literasi Keuangan Pada Generasi Z. Jurnal Pendidikan Akuntansi (JPAK), 9(1), 131-139. Retrieved from https://ejournal.unesa. ac.id/index.php/jpak/article/view/39272 
Marina, D. (2020). Konsumerisme Di Era Digital. http://jurnal.stiks-tarakanita.ac.id/index.php/ forum/article/download/328/197

Ni'matuzahroh, \& Prasetyaningrum, S. (2018). Observasi: Teori dan Aplikasi dalam Psikologi. In Universitas Muhammadiyah Malang. Universitas Muhammadiyah Malang.

Noya, A. B. I. (2021, July 26). Memilih Mainan Anak Sesuai Usia. Alodokter. https://www.alodokter.com/memilih-mainan-anak-sesuai-usia

Ramadhini, E. S. (2021, June 10). 7 Rekomendasi Mainan Edukatif Balita untuk Asah Kreativitasnya. theAsianparent: Situs Parenting Terbaik di Indonesia. https://id.theasianparent. com/mainan-edukatif-balita.

Setianingsih, E. S. (2019). Wabah Gaya Hidup Hedonisme Mengancam Moral Anak. Malih Peddas (Majalah Ilmiah Pendidikan Dasar), 8(2), 130. doi:10.26877/malihpeddas.v8i2.2844.
Sumiyati. (2017). Mengenalkan Pengelolaan Keuangan Pada Anak Sejak Usia Dini. Islamic Review Jurnal Riset Dan Kajian Keislaman, VI, 1st ser., 29-47. Retrieved August 22, 2020.

Wahyudi, R., \& Linawati, N. (2017). Peran Edukasi Keuangan di Usia Dini Untuk Membangun Kemandirian Keuangan. In Seminar Nasional Hasil Pengabdian kepada Masyarakat 2017. Malang: Universitas kanjuruhan malang.

Wisnubrata. (2020, June 2). Membentuk Anak Cerdas dengan Stimulasi Sejak Dini Halaman all - Kompas.com. KOMPAS.Com. https://lifestyle.kompas.com/read/2020/06/02/122725320/ membentuk-anak-cerdas-dengan-stimulasisejak-dini?page $=$ all.

Zaman, B. (2011). Pengembangan Alat Permainan Edukatif di Lembaga Pendidikan Anak Usia Dini (PAUD) [Pdf]. Jakarta: Universitas Pendidikan Indonesia. 